\title{
DAMPAK MANAJEMEN PERUBAHAN LINGKUNGAN KERJA MASA PANDEMI COVID-19 TERHADAP PEGAWAI PT. TELKOM INDONESIA TBK DIVREG 3 JAWA BARAT
}

\author{
Resty Ismawanti \\ Program Studi Akuntansi, Universitas Sangga Buana \\ Bandung, Jawa Barat, Indonesia \\ restyisrand12@gmail.com
}

\begin{abstract}
ABSTRAK
WHO (World Health Organization atau Badan Kesehatan Dunia) secara resmi mendeklarasikan virus corona (COVID-19) sebagai pandemi pada tanggal 9 Maret 2020. Setelah adanya pandemi covid 19 orang yang memiliki keperluan masih banyak, sehingga pimpinan harus membuat kebijakan untuk menjaga keselamatan karyawan maupun pelanggan. Tujuan penelitian ini untuk mengetahui dan menganalisis dampak manajemen perubahan lingkungan kerja masa pandemi COVID-19 terhadap pegawai PT Telkom Indonesia Tbk DIVREG 3 Jawa Barat. Dampak manajemen perubahan lingkungan kerja masa pandemi COVID-19 terhadap pegawai PT Telkom Indonesia Tbk DIVREG 3 Jawa Barat yaitu manajemen membutuhkan sistem yang dapat membantu seluruh tim berkoordinasi guna memastikan operasional bisa berjalan dengan baik. Bagi PT Telkom Indonesia Tbk DIVREG 3 Jawa Barat yang menerapkan work from office (WFO), perusahaan pun disarankan untuk menyiapkan protokol kesehatan untuk melindungi karyawan dari bahaya Covid-19, mulai dari melakukan deteksi suhu, penyemprotan disinfektan, hingga penyediaan masker bagi karyawan.
\end{abstract}

Kata kunci: Manajemen, Perubahan Lingkungan Kerja, Covid-19

\section{ABSTRACT}

WHO (World Health Organization) officially declared the corona virus (COVID-19) as a pandemic on March 9 , 2020. After the COVID-19 pandemic, 19 people had many needs, so leaders had to make policies to maintain the safety of employees and customer. The purpose of this study was to determine and analyze the impact of management of changes in the work environment during the COVID-19 pandemic on employees of PT Telkom Indonesia Tbk DIVREG 3, West Java. The impact of management of changes in the work environment during the COVID-19 pandemic on employees of PT Telkom Indonesia Tbk DIVREG 3 West Java, namely that management requires a system that can help the entire team coordinate to ensure operations can run well. For PT Telkom Indonesia Tbk DIVREG 3 West Java, which implements work from office (WFO), companies are also advised to prepare health protocols to protect employees from the dangers of Covid-19, starting from temperature detection, spraying disinfectants, to providing masks for employees.

Keywords: Management, Work Environment Change, Covid-19.

\section{PENDAHULUAN}

WHO (World Health Organization atau Badan Kesehatan Dunia) secara resmi mendeklarasikan virus corona (COVID-19) sebagai pandemi pada tanggal 9 Maret 2020. Artinya, virus corona telah menyebar secara luas di dunia. Istilah pandemi terkesan menakutkan tetapi sebenarnya itu tidak ada kaitannya dengan keganasan penyakit tapi lebih pada penyebarannya yang meluas. Ingat, pada umumnya virus corona menyebabkan gejala yang ringan atau sedang, seperti demam dan batuk, dan kebanyakan bisa sembuh dalam beberapa minggu. Tetapi bagi sebagian orang yang berisiko tinggi (kelompok lanjut usia dan orang dengan masalah kesehatan menahun, seperti penyakit jantung, tekanan darah tinggi, atau diabetes), virus corona dapat menyebabkan masalah kesehatan yang serius. 


\section{Kebijakan: Jurnal Ilmu Administrasi \\ Volume 12, Nomor 1, Januari 2021 \\ E-ISSN: 2656-2820 \\ P-ISSN 1829-5762}

Kebanyakan korban berasal dari kelompok berisiko itu (https://covid19.go.id/tanyajawab?search=Gejala+virus+Corona, diakses: 26 Oktober 2020. Dalam 24 jam terakhir, Satuan Tugas Penanganan Covid-19 melaporkan penambahan 112 kasus kematian. Dengan demikian, total pasien Covid-19 meninggal dunia, yaitu 13.411 orang. Maka, hingga tanggal 26 Oktober 20020 ada 392.934 kasus Covid-19 di Tanah Air. Sementara itu, ada penambahan 3.908 pasien Covid-19 sembuh, sehingga total pasien sembuh kini menjadi 317.672 orang.

Melansir data dari laman Worldometers, Senin (26/10/2020), jumlah total kasus Covid-19 saat ini tercatat 43,3 juta kasus. Dari angka tersebut, telah terjadi lebih dari 1,1 juta kasus kematian dan 31,8 juta pasien telah dinyatakan sembuh. Adapun jumlah kasus aktif saat ini adalah 10,2 juta, dengan 10,1 juta dalam kondisi ringan dan 77.726 dalam kondisi serius atau kritis. Jumlah total kasus terbanyak masih dicatatkan oleh Amerika Serikat (AS) dengan lebih dari 8 juta kasus, disusul India, Brasil, Rusia, dan Perancis. Kondisi pandemi Covid-19 ini pun masih terus mengalami perubahan dari waktu.

PT. Telekomunikasi Indonesia Divreg 3 Jawa Barat merupakan salah satu badan usaha berlabel Badan Usaha Milik Negara (BUMN) serta menjadi penyedia layanan telekomunikasi dan jaringan terbesar di Indonesia. Telkom menyediakan layanan Information and Communication, telepon kabel (fixed wireline), telepon nirkabel (fixed wireless), layanan telepon seluler, data dan internet yaitu dengan produk Indihome, serta jaringan interkoneksi, baik secara langsung maupun melalui anak perusahaan, seperti Telkomsel. Sebelum adanya pandemi covid 19, PT Telkom Indonesia Tbk DIVREG 3 Jawa Barat selalu ramai dengan antrian yang cukup panjang namun pelayanannya tetap baik dan menyenangkan. Setelah adanya pandemi covid 19 orang yang memiliki keperluan masih banyak, sehingga pimpinan harus membuat kebijakan untuk menjaga keselamatan karyawan maupun pelanggan.

Beberapa solusi yang bisa dimanfaatkan pelanggan di antaranya mulai dari CCTV Thermal, Tablet Camera Thermal, aplikasi AdsQoo serta layanan Shared Service. CCTV Thermal adalah alat untuk mendeteksi suhu tubuh individu di tengah kerumunan orang sedangkan Tablet Camera Thermal digunakan untuk mendeteksi suhu yang sekaligus dilengkapi dengan fitur face recognition untuk mengenali penggunakan masker atau tidak. Perangkat kamera yang mendeteksi suhu tubuh ini dapat diintegrasikan dengan berbagai kebutuhan perusahaan seperti untuk HR information system, building management \& security system, ticketing system, smart parking system, serta sistem lain yang menggunakan API .

Solusi Thermal Camera yang dilengkapi face recognition dan mudah diintegrasikan dengan berbagai sistem manajemen ini akan sangat dibutuhkan oleh berbagai bidang usaha seperti mall, rumah sakit, perkantoran, apartemen, sekolah dan perguruan tinggi, pabrik, pergudangan, instansi pemerintah, serta area publik lainnya. Layanan shared service ini dijalankan oleh entitas anak usaha Telkom, Infomedia yang memiliki pengalaman puluhan tahun di bidang penyedia shared service. Dari benchmark di negara lain yang telah lebih awal mengimplementasikan shared service, Bogi mengatakan bahwa kelebihan shared service ini bukan hanya soal memangkas biaya, tetapi juga mengoptimalkan performansi perusahaan dengan penerapan digital process. Tujuan penelitian ini untuk mengetahui dan menganalisis dampak manajemen perubahan lingkungan kerja masa pandemi COVID-19 terhadap pegawai PT Telkom Indonesia Tbk DIVREG 3 Jawa Barat.

\section{METODE}

Metode penelitian kualitatif dengan pendekatan studi kasus.

a. $\quad$ Perencanaan (Planning)

Perencanaan berarti kegiatan menetapkan tujuan organisasi dan memilih cara yang terbaik untuk mencapai tujuan tersebut. Pengambilan keputusan merupakan bagian dari perencanaan yang berarti 


\section{Kebijakan: Jurnal Ilmu Administrasi \\ Volume 12, Nomor 1, Januari 2021 \\ E-ISSN: 2656-2820 \\ P-ISSN 1829-5762}

menentukan atau memilih alternatif pencapaian tujuan dari beberapa alternatif yang ada. Perencanaan diperlukan untuk mengarahkan kegiatan organisasi. Langkah pertama, rencana ditetapkan untuk organisasi secara keseluruhan. Kemudian, rencana yang lebih detail untuk masingmasing bagian atau divisi ditetapkan, dengan cara semacam itu, organisasi mempunyai perencanaan yang konsisten secara keseluruhan. Beberapa manfaat perencanaan adalah (1) mengarahkan kegiatan organisasi yang meliputi penggunaan sumberdaya dan penggunaannya untuk mencapai tujuan organisasi, (2) memantapkan konsistensi kegiatan anggota organisasi agar sesuai dengan tujuan organisasi, dan (3) memonitor kemajuan organisasi. Jika organisasi berjalan menyimpang dari tujuan yang telah ditetapkan, dapat dilakukan perbaikan. Manfaat nomor tiga tersebut erat kaitannya dengan kegiatan pengendalian. Pengendalian memerlukan perencanaan dan perencanaan bermanfaat bagi pengendalian.

b. Pengorganisasian (Organizing dan Staffing)

Tahap berikutnya adalah pengorganisasian. Pengorganisasian dapat diartikan sebagai kegiatan mengoordinasi sumberdaya, tugas, dan otoritas diantara anggota organisasi agar tujuan organisasi dapat dicapai dengan cara yang efisien dan efektif. Sebagai contoh, kegiatan perusahaan kebanyakan diorganisasi berdasarkan fungsi pokok perusahaan, seperti pemasaran, keuangan, produksi, administrasi, dan personalia. Masing-masing dikelompokkan menjadi departemen atau bagian sendiri. Masing-masing bagian dipimpin oleh manajer yang bertanggung jawab kepada direktur utama.

c. Pengarahan (Leading)

Setelah struktur organisasi ditetapkan, orang-orangnya ditentukan. Langkah selanjutnya adalah membuat bagaimana orang-orang tersebut bekerja untuk mencapai tujuan organisasi. Manajer perlu "mengarahkan" orang-orang tersebut. Lebih 1 spesifik lagi pengarahan -meliputi kegiatan memberi pengarahan (directing), memengaruhi orang lain (influencing), dan memotivasi orang tersebut untuk bekerja (motivating). Pengarahan biasanya dikatakan sebagai kegiatan manajemen yang paling menantang dan paling penting karena langsung berhadapan dengan manusia.

Bagaimana membuat orang lain bekerja untuk tujuan organisasi merupakan pekerjaan yang tidak mudah. Manajer harus mampu menciptakan suasana (atmosfer) yang bisa mendorong orang untuk bekerja. Cara yang dipakai mungkin sangat berlainan dari satu organisasi ke organisasi lain. Microsoft, perusahaan pembuat perangkat lunak (software) di Amerika Serikat, membuat suasana kerja yang sangat longgar. Karyawan yang terdiri atas para pemrogram (programmer) tidak mempunyai jam kerja tertentu. Mereka dapat masuk dan keluar kapan saja dan biasanya justru keluar kantor malam hari. Mereka tidak perlu memakai seragam, boleh datang dengan T-Shirt atau celana jeans. Di tempat kerja, disediakan meja biliar atau minuman ringan (softdrink) bebas. Prinsipnya, asal pekerjaan mereka selesai dan mereka bisa menghasilkan software yang baik, tidak ada masalah dengan peraturan kerja. Suasana semacam itu barangkali mirip dengan perguruan tinggi, yaitu staf pengajar bisa keluar masuk kapan saja. Akan tetapi, suasana ang longgar semacam itu tidak akan berhasil apabila diterapkan di organisasi militer yang membutuhkan disiplin yang tinggi. Barangkali juga tidak akan berhasil apabila diterapkan di perusahaan manufaktur yang memproduksi barang yang berstandar, tempat kreativitas tidak begitu penting. Perusahaan semacam itu membutuhkan disiplin kerja yang baik.

d. Pengendalian (Controlling)

Elemen terakhir proses manajemen adalah pengendalian. Pengendalian bertujuan melihat apakah kegiatan organisasi sesuai dengan rencana. Manajer harus selalu memonitor kemajuan organisasi. Fungsi pengendalian meliputi empat kegiatan: (1) menentukan standar prestasi, (2) mengukur prestasi yang telah dicapai selama ini, (3) membandingkan prestasi yang telah dicapai dengan standar 
prestasi, dan (4) melakukan perbaikan jika ada penyimpangan dari standar prestasi yang telah ditentukan.Kemudian, kembali lagi ke fungsi perencanaan untuk periode berikutnya.

e. Proses Manajemen dalam Praktik

Semua manajer melakukan empat fungsi yang telah dibicarakan (planning, organizing, leading, dan controlling). Meskipun demikian, dalam praktik gambaran semacam itu tidak begitu terlihat. Seringkali kita melihat kegiatan manajer yang sibuk kesana kemari yang sepertinya tidak punya waktu untuk berpikir dan merencanakan sesuatu dengan tenang. Aktivitas manajer dalam praktik sepertinya reaktif, bereaksi terhadap suatu kejadian. Mereka lebih action oriented. Model proses manajemen seperti yang digambarkan di muka tampaknya tidak sesuai dengan praktik manajemen. Jika diperhatikan, manajer tetap melakukan empat fungsi manajemen tadi. Manajer melakukan perencanaan meskipun kadang-kadang rencana tadi ditetapkan dalam waktu yang sangat singkat. Pada waktu manajer berteriak menyuruh bawahan untuk menyelesaikan pekerjaan dengan cepat, ia sedang melakukan fungsi pengarahan. Cuma urutan yang digambarkan oleh garis tebal (pada gambar proses manajemen) tidak sepenuhnya tepat. Pada praktiknya, manajer sering melompat-lompat dalam melakukan empat fungsi tadi. Sebagai contoh, manajer melakukan perencanaan, kemudian langsung memberi pengarahan. Garis yang terputus-putus lebih tepat menggambarkan urutan fungsi manajemen dalam praktiknya. Keempat fungsi manajemen dilakukan secara interaktif dan kadangkadang secara simultan. Manajer dapat dikelompokkan berdasarkan tingkatan dan bidangnya. Berdasarkan tingkatannya, manajer dibagi dalam (1) manajer tingkat bawah(first line), (2) manajer menengah (middle), dan (3) manajer tingkat atas (top). Berdasarkan bidangnya, secara umum manajer dapat dikelompokkan ke dalam dua pengelompokkan: (1) manajer umum (general) dan (2) manajer fungsional. Manajer fungsional dapat 1 dikelompokkan 1 berdasarkan bidangnya: (1) manajer pemasaran, (2) manajer keuangan, (3) manajer operasi, (4) manajer sumberdaya manusia (personalia), dan (5) manajer lainnya.

\section{PEMBAHASAN}

1. Kondisi perubahan lingkungan kerja masa pandemi COVID-19 terhadap pegawai PT Telkom Indonesia Tbk DIVREG 3 Jawa Barat

PT Telekomunikasi Indonesia (Persero) Tbk. kinerja perseroan masih berlangsung baik saat masa pandemi Covid-19. Manajemen PT Telkom Indonesia Tbk DIVREG 3 Jawa Barat menjelaskan pandemi Covid-19 tidak berpengaruh terhadap kelangsungan usaha perseroan. Kondisi keuangan perseroan pun tidak terganggu. Akan tetapi ada beberapa kendala salah satunya kendala pada customer. Kendala yang dimaksud seperti adanya pembatasan fisik, terdapat kendala dalam pemasangan instalasi IndiHome ke rumah-rumah pelanggan. Dari sisi consumer/customer, PT Telkom Indonesia Tbk DIVREG 3 Jawa Barat mengklaim IndiHome terus melanjutkan momentum positif dan menjadi pendorong pertumbuhan perseroan. IndiHome mencatat kenaikan pendapatan signifikan sebesar 28,1 persen menjadi Rp 18,3 triliun.

2. Manajemen Perubahan Lingkungan Kerja Masa Pandemi COVID-19 terhadap pegawai PT Telkom Indonesia Tbk DIVREG 3 Jawa Barat

Manajemen perubahan lingkungan kerja masa pandemi COVID-19 yang diberlakukan terhadap pegawai PT Telkom Indonesia Tbk DIVREG 3 Jawa Barat yaitu:

a. Adanya pembatasan fisik, terdapat kendala dalam pemasangan instalasi IndiHome ke rumahrumah pelanggan.

b. Pimpinan membuat kebijakan untuk menjaga keselamatan karyawan maupun pelanggan. Kebijakan yang ditetapkan terkait dengan perubahan lingkungan kerja non fisik meliputi standar 
dan prosedur harus menggunakan masker dan sarung tangan, tidak bersentuhan dengan rekan maupun pelanggan, mewajibkan sering cuci tangan bagi karyawan dan penyemprotan hand sanitizer pada pelanggan yang datang, membatasi pelanggan yang masuk ke toko agar tidak berjubel, dan tidak boleh melayani pelanggan yang tidak menggunakan masker.

c. PT Telkom Indonesia Tbk DIVREG 3 Jawa Barat secara proaktif terus melakukan berbagai kegiatan preventif bagi karyawan di lingkungan kerja, baik yang bekerja di kantor maupun yang bekerja dari rumah, yang keseluruhannya diawasi secara kontinyu melalui satuan tugas yang dibentuk untuk penanganan pandemi virus Covid-19.

d. Budaya kerja TelkomGroup telah berorientasi pada teknologi digital melalui pemanfaatan berbagi aplikasi digital untuk perkantoran seperti Diarium, aplikasi Nota Dinas Elektronik, Portal Internal ataupun berbagai aplikasi pengeloaan Human Capital, hingga untuk keperluan komunikasi video conference dengan menggunakan aplikasi CloudX dan UMeetMe.

e. Untuk kebutuhan pelanggan, produk-produk TelkomGroup telah dilengkapi dengan dukungan aplikasi dan berbagai kanal digital maupun media sosial. Seperti halnya IndiHome yang menyediakan aplikasi MyIndiHome bagi pelanggannya untuk mengelola layanan IndiHomenya disamping juga telah tersedia layanan pelanggan melalui media sosial @IndiHome di twitter, Instagram serta di Facebook. Tidak hanya itu, pelanggan juga dapat menghubungi customer care IndiHome melalui email customercare@telkom.co.id atau telepon ke 147 sehingga pelanggan tidak perlu bepergian ke luar rumah apabila ingin mengelola layanan IndiHome-nya. Meskipun juga Grapari TelkomGroup ataupun Plasa Telkom akan siap beroperasi penuh dengan penerapan protokol kesehatan seperti melakukan pengecekan suhu kepada semua orang yang memasuki lokasi, penggunaan masker, hand sanitizer serta pengaturan physical distancing.

3. Dampak Manajemen Perubahan Lingkungan Kerja Masa Pandemi COVID-19 terhadap pegawai PT Telkom Indonesia Tbk DIVREG 3 Jawa Barat

Dampak manajemen perubahan lingkungan kerja masa pandemi COVID-19 terhadap pegawai PT Telkom Indonesia Tbk DIVREG 3 Jawa Barat yaitu manajemen membutuhkan sistem yang dapat membantu seluruh tim berkoordinasi guna memastikan operasional bisa berjalan dengan baik. Bagi pegawai PT Telkom Indonesia Tbk DIVREG 3 Jawa Barat yang menerapkan work from office (WFO), perusahaan pun disarankan untuk menyiapkan protokol kesehatan untuk melindungi karyawan dari bahaya Covid-19, mulai dari melakukan deteksi suhu, penyemprotan disinfektan, hingga penyediaan masker bagi karyawan.

\section{SIMPULAN}

Dampak manajemen perubahan lingkungan kerja masa pandemi COVID-19 terhadap pegawai PT Telkom Indonesia Tbk DIVREG 3 Jawa Barat yaitu manajemen membutuhkan sistem yang dapat membantu seluruh tim berkoordinasi guna memastikan operasional bisa berjalan dengan baik. Bagi PT Telkom Indonesia Tbk DIVREG 3 Jawa Barat yang menerapkan work from office (WFO), perusahaan pun disarankan untuk menyiapkan protokol kesehatan untuk melindungi karyawan dari bahaya Covid19, mulai dari melakukan deteksi suhu, penyemprotan disinfektan, hingga penyediaan masker bagi karyawan. 


\section{DAFTAR PUSTAKA}

Bernardin, H. John, danJoyce E.A Russel.2010. Human resource management (An Experimental Approach International Editio). Mc. Graw -Hill Inc.Singapore

Creswell, J. W.2010. Research Design Pendekatan Kualitatif, Kuantitatif dan Mixed. Yogyakarta: Pustaka Pelajar.

Hamdiyah, Haryono, A. T., \& Fathoni, A. 2016. Peningkatan Kinerja Karyawan Melalui Kompensasi, Lingkungan Kerja dan Gaya Kepemimpinan di Swalayan Banyumanik Semarang. Journal of Management, 02(02), 1-11.

Meilina, R.2017. Pelayanan Publik Dalam Perspektif MSDM (Tinjauan dari Dimensi OCB, Kepuasan Kerja, dan Komitmen Organisasi). Kediri: Fakultas Ekonomi Universitas Nusantara PGRI Kediri.

Rivai, Veithzal. 2010. Performance Appraisal : Sistem yang Tepat Untuk Menilai Kinerja Pegawaidan Meningkatkan Daya Saing Perusahaan. Jakarta:

PT. Raja Grafindo Persada. 